\title{
Pendidikan Islam Muslim Minoritas \\ (Kasus di Eropa Barat)
}

\author{
Dedi Sahputra Napitupulu \\ Sekolah Tinggi Ilmu Tarbiyah (STIT) AL-Ittihadiyah Labuhanbatu Utara \\ dedisahputranapitupulu@yahoo.com
}

\author{
Syawal Fahmi \\ Universitas Islam Negeri (UIN) Sumatera Utara \\ fahmi23868@gmail.com
}

\begin{abstract}
This research is a library study using descriptive analysis. The study aims to find out the education of Islamic minority Muslim cases of European countries. The results showed that the Muslim growth pattern of 20-21 century was through the immigration of Muslims to the minority countries is due to the prolonged conflict in their home country. In addition, the most prominent cause of Muslim propagation is the more promising economic factors in European countries. The patterns of minority Muslim education are to maximize the functioning of the mosque as an Islamic educational institution, establishing the majelis taklim and Madrasah. As for the opportunities of Muslims in the minority area is a strong encouragement and motivation to get out of pressure. While the obstacle is the orientation of education is less obvious, human resources (SDM) are not adequate.
\end{abstract}

Keywords: Islamic Education, Muslim, Minority

Abstrak: Penelitian ini merupakan studi pustaka dengan menggunakan analisis deskriptif. Penelitian ini bertujuan untuk mengetahui pendidikan Islam Muslim minoritas kasus negara-negara Eropa. Hasil penelitian menunjukkan bahwa Pola pertumbuhan Muslim abad 20-21 adalah melalui imigrasi umat Muslim ke negaranegara minoritas adalah karena konflik yang berkepanjangan di negara asal mereka. Selain itu, penyebab yang paling utama dalam hal penyebaran muslim adalah faktor ekonomi yang lebih menjanjikan di negara-negara Eropa. Pola-pola pendidikan Muslim minoritas adalah dengan memaksimalkan fungsi masjid sebagai lembaga pendidikan Islam, mendirikan majelis taklim dan madrasah. Adapun yang menjadi peluang umat Muslim di daerah minoritas

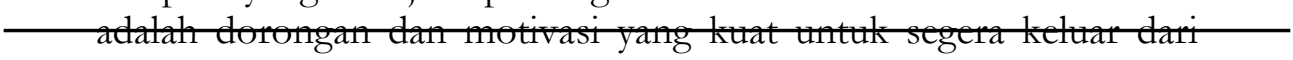

Belajea: Jurnal Pendidikan Islam Vol. 5, No 01, 2020; 157-164 p-ISSN 2548-3390; e-ISSN 2548-3404, DOI:10.29240/belajea.v4i2.891 available online at:http://journal.staincurup.ac.id/indek.php/belajea 
38 | Belajea: Jurnal Pendidikan Islam, Vol. 5, No. 01, 2020

tekanan. Sedangkan yang menjadi penghambat adalah orientasi pendidikan yang kurang jelas, sumber daya manusia (SDM) yang belum memadai.

Kata Kunci: Pendidikann Islam, Minoritas, Eropa

\section{Pendahuluan}

Merupakan sebuah keniscayaan, jika hendak mengukur kemajuan peradaban Islam di suatu tempat dengan memperhatikan kualitas lembaga pendidikannya. Tentu variabel pendidikan Islam tidak tunggal, masih banyak variabel lain yang bisa dijadikan tolok ukur peradaban Islam, seperti ekonomi, politik, sosial, budaya dan lain sebagainya. Uraian berikut ini akan secara spesifik menggiring pembaca kepada aspek pendidikan Islam saja. Itu pun hanya fokus di daerah minoritas Muslim saja.

Bagi masyarakat yang berada di daerah minoritas Muslim, tentu tidak mudah untuk bertahan di tengah kepungan orang yang tidak seagama dengan kita. Perlu mental yang kuat dan motivasi penyesuaian diri yang tinggi agar dapat tetap eksis dalam satu komunitas. Demikian juga halnya dengan pendidikan Islam yang berada di daerah-dareh minoritas Muslim. Tentu banyak sekali likaliku perjalanan dan perjuangan yang mesti dilalui. Hal inilah yang membuat pembahasan dalam tulisan ini menjadi lebih menarik. Jika kita amati secara seksama tentang letak geografis dan sebaran umat Islam diseluruh dunia, maka data statistik terakhir menunjukkan lebih kurang umat Islam berjumlah 1,7 milliar, sebuah data kuantitaif yang lumayan besar. Apalagi belakangan ini perkembangan umat Islam khususnya di Eropa semakin bertambah secara kuantitas. Hal ini tentu berdampak pada benturan budaya antara Timur dan Barat, sehingga menarik untuk ditelusuri lebih lanjut.

Dengan menggunakan metode studi pustaka dan analisis deskriptif tulisan ini akan mencoba menguraikan tentang statistik kependudukan berdasarkan etnis dan agama, pola pertumbuhan Muslim abad 20 dan 21, polapola pendidikan agama umat Islam, serta prospek dan tantangannya. 


\section{Pembahasan}

\section{Statistik Kependudukan Berdasarkan Etnis dan Agama}

Menurut data dari Pew Research Center's Forum on Religion \& Public Life ada sekitar 1,8 miliyar penduduk Muslim yang tersebar di seluruh penjuru dunia. Dari data tersebut lebih separuh di antara penduduk Muslim berada di Asia Pasifik, 20 \% dan selebihnya berada Amerika, Eropa dan Australia. ${ }^{1}$ Dari data tersebut dapat dikalkulasikan bahwa ada dua pertiga penduduk Muslim dunia tinggal di kawasan Asia Pasifik dan hanya seperlima saja yang berada di wilayah Timur Tengah dan Afrika Utara, yang menggunakan bahasa Arab.

Populasi Muslim di dunia diramalkan akan terus bertambah sampai 30\% pada tahun 2030 mendatang. Tingkat pertumbuhan penduduk Muslim diperkirakan mencapai dua kali lipat dibandingkan non-Muslim, di mana ratarata pertumbuhan Muslim pertahun berkisar 1,5\% sementara non-Muslim hanya berkisar $0,7 \%$ pertahun. Perkiraan pertumbuhan penduduk Muslim ini didasarkan pada data time series, di mana pada tahun 1990 jumlah penduduk Muslim mencapai 1,1 miliyar, tahun 2000 mencapai 1,3 miliyar dengan nilai pertumbuhan 19,9\%, tahun 2010 mencapai 1,6 miliyar dengan nilai pertumbuhan $21,6 \%$, tahun 2020 diprediksi mencapai 1,9 miliyar dengan nilai pertumbuhan 23,4\%, dan tahun 2030 diproyeksikan mencapai 2,2 miliyar dengan nilai pertumbuhan $24,9 \%$. Dengan demikian, Islam akan menjadi agama yang memiliki perkembangan pemeluk terbanyak di dunia. Artinya, kaum Muslim akan mencapai $26,4 \%$ dari total populasi penduduk bumi yang diproyeksikan mencapai 8,3 miliyar pada tahun 2030. Kalau mau lebih singkat, seperti yang diungkapkan oleh Bahrul Hayat, bahwa nanti: "satu dari empat penduduk yang ada di bumi nantinya adalah seorang Muslim".

Islam adalah agama terbesar ke dua di Eropa setelah Kristen. Meskipun sebagian besar mereka adalah berasal dari para imigran. Muslim di Eropa terdapat di Bosnia, Herzegovina, Albania, Kosovo, beberapa wilayah di Bulgaria, Macedonia dan Montenegro, serta beberapa di wilayah Rusia. Mengenai tradisi

\footnotetext{
${ }^{1}$ Pew Research Center's Forum on Religion \& Public Life, World Muslim Population by County, dirilis pada 17 November, 2017.

${ }^{2}$ Bahrul Hayat, "Kontribusi Islam Terhadap Masa Depan Peradaban Islam di Asia Tenggara”, dalam Jurnal Miqot, Vol. XXXIV, no. 1, Januari-Juni (2012), hlm. 193.
} 
40 | Belajea: Jurnal Pendidikan Islam, Vol. 5, No. 01, 2020

Islam mereka konsisten mengamalakan bagaimana ajaran Islam yang lahir terdahulu. $^{3}$

Melihat data-data statistik di atas maka fokus tulisan ini adalah bukan pada besarnya penduduk Muslim di suatu daerah, melainkan pada daerah-daerah yang berpenduduk minoritas Muslim. Dalam konteks pendidikan Islam, adalah sebuah kewajaran jika lembaga-lembaga pendidikan Islam, atau kajian-kajian keislaman tumbuh subur di lahannya sendiri. Akan tetapi yang lebih menarik perhatian adalah jika pendidikan Islam tumbuh subur dan berkembang pada lahan yang gersang (daerah minoritas).

\section{Pola Pertumbuhan Muslim Abad 20-21}

Berbicara mengenai pola pertumbuhan penduduk, terlepas dari apapun agamanya, biasanya ditandai dengan tingkat kelahiran yang lebih tinggi dibandingkan dengan tingkat kematian. Sebagaimana agama yang lain, Islam menyebar dari Timur hingga ke Barat dan seluruh penjuru dunia merupakan bagian dari misi Islam itu sendiri. Barat sebagai bangsa yang mengalami masa suramnya, dengan mudah dapat menerima Islam yang kala itu memang sedang mengalami kejayaannya. Sebagian sarjana Muslim melihat, kejayaan Islam itu ada karena di ilhami oleh para tokoh-tokoh Yunani.

Berdasarkan tinjauan historis, bahwa Eropa lebih kental dengan agama Kristen dan Yahudi. Walau demikian, dengan kehadiran Islam di Eropa memberi nuansa baru dalam memberikan peradaban di Eropa. Tahun 711 Masehi merupakan perjumpaan Eropa dengan Islam pertama kali saat itu Tariq bin Ziyat melintasi selat Gibraltar menaklukkan kerajaan Visigoth. ${ }^{4}$ Negara Eropa merupakan negara penganut paham kebebasan, sehingga ketika terjadi penaklukan oleh Napoleon ke negara-negara Islam sehingga dapat dikatakan bahwa hampir seluruh negeri Muslim pada penghujung abad ke-19 dikuasai oleh Barat. Hampir seluruh negeri Muslim tidak ada yang tidak tersentuh oleh penetrasi Barat. ${ }^{5}$

Rupanya Barat tidak secara langsung telah memperhatikan pergerakan umat Islam, yang memang secara faktual dapat dibuktikan keberhasilannya dalam ilmu pengentahuan dan teknologi, terutama dalam bidang kesehatan.

\footnotetext{
${ }^{3}$ Joseph F. O'Callagan, A History of Medieval Spain (New York: Cornell University Press, 1983), hlm. 142.

${ }^{4}$ Hasan Asari, Menyingkap Zaman Keemasan Islam (Bandung: Mizan, 2007), hlm. 5.

${ }^{5}$ Philip K. Hitti, History of Arabs, Terj. Cecep Lukman Yasin dan Dedi Slamet Riyadi (Jakarta: Serambi Ilmu Semesta, 2010), hlm. 942.
} 
Melihat data yang sudah penulis temukan, Islam menyeberang ke dunia Barat dibawa panglima Thariq bin Ziyad. ${ }^{6}$ Bangsa Eropa yang diwaktu itu dalam keadaan sulit, sebab usainya perang dunia kedua yang baru saja mereka alami, keadaan ekonomi dan politik mereka dalam keadaan kacau. Dengan keadaan yang seperti itu, mereka ingin memulihkan kembali keadaan mereka, tentu saja memerlukan tenaga (buruh), juga termasuk tenaga ahli. Maka dengan demikian datangnya Islam kedaerah tersebut lebih mudah untuk bergabung.

Penyebaran imigran Muslim di Eropa sekarang mencerminkan wilayah penjajahan masa lalu. Kebanyakan imigran yang menetap di Prancis adalah orang Maroko, Aljazair, dan sejumlah Muslim Afrika dari Selatan Sahara. Mereka semua, awalnya dijajah Prancis. Kebanyakan orang Indonesia menempati Belanda. Adapun Inggris banyak ditempati imigran dari anak benua India, Malaysia, dan sejumlah orang Yaman, Somalia, dan Afrika Utara. Sedangkan Jerman agak berbeda, imigran yang ada kebanyakan orang Turki, Maroko, dan yang lainnya tidak ada kaitan dengan pengaruh Jerman. Sekalipun mereka orang Muslim, namun gaya hidup masing-masing sesuai dengan kebiasaan dan sikap hidup yang dibawa dari negeri asalnya menunjukkan perbedaan. ${ }^{7}$

Kemajuan dan penyebaran agama Islam, mulai mendominasi Timur Tengah dari Afrika Utara seperti Spanyol di Eropa. Wilayahnya bahkan lebih besar dari Romawi. Setelah orang Islam dari Arab menaklukkan Afrika Utara, giliran Afrika Utara yang di-Islam-kan berusaha masuk Eropa melalui Spanyol. Mereka berhasil menduduki sebagian wilayah Spanyol, tetapi pada akhirnya dikalahkan di Paiter oleh Karel Martel pada tahun 732 M. Namun mereka masih tetap berkuasa di Spanyol hingga tahun 1200-an. Pada tahun 1000-an, orang Islam dari Turki menaklukkan Timur Tengah dan sebagian besar Eropa Tenggara. Pada awal tahun 1300-an kelompok Islam Turki lainnya yaitu Turki Ottoman mulai menguasai seluruh wilayah ini. Pada pertengahan abad ke-16 M, kerajaan Turki Ottoman meliputi sebagian besar Timur Tengah, Afrika Utara, dan Eropa Tenggara. Turki Ottoman menguasai wilayah ini hingga tahun sampai saat ini.

Kebanyakan di negara-negara yang mengalami konflik, khususnya di Timur Tengah, telah banyak membuat pembauran masyarakat secara global, bagaimana tidak para imigran yang merasa "terancam" dinegara mereka memutuskan untuk pindah untuk mencari ketenangan dan keamanan dinegara

${ }^{6}$ Ajid Thohir, Perkembangan Peradaban Dunia Islam: Melacak Akar-Akar Sejarah, Sosial, Politik, dan Budaya Umat Islam (Jakarta: Rajawali Press, 2009), hlm. 329.

${ }^{7}$ Ibid., hlm. 330. 
42 | Belajea: Jurnal Pendidikan Islam, Vol. 5, No. 01, 2020

lain, tercatat yang menjadi Negara tujuan adalah Eropa namun tidak begitu banyak para imigran itu datang ke Asia, karena mungkin secara geografis terlalu jauh jika dibandingkan Eropa. Selain itu, Eropa adalah benua yang secara umum dikatan kuat dan maju.

Dapat kita lihat fakta yang ada, kalau Negara yang terjajah seperti Iraq, Afganistan, Libiya, Palestina dan lain-lain menyisakan permasalahan besar bagi masyarakat muslim. Hal itu dapat dilihat bahwa kerusakan tatanan masyarakat, status sosial, tempat tinggal dan kebanyakan mereka semua mengalami permasalahan berat dinegara mereka sendiri. Maka dalah keadaan yang seperti itu kebanyak mereka memutuskan untuk hijrah dinegara-negara yang mereka anggap lebih aman.

Namun sebagian lain karena tuntutan gaya hidup dan faktor ekonomi yang lebih menggiurkan. Keadaan yang mapan dinegara-negara Eropa menjadi daya tarik bagi mereka untuk mengadakan komunikasi baik dalam perdagangan hingga hubungan politik. Dalam dunia modern di Amerika terjadi penguatan dan pemusatan kekuasaan pada negara. Perkembangan yang baru tersebut menyebabkan adanya konflik. Di satu pihak adalah kelompok-kelompok agama, sedangkan di lain pihak adalah persuasi politik.

Kelompok keagamaan berpendapat bahwa masalah-masalah moral seperti itu bukanlah tugas negara. Akan tetapi, yang terjadi adalah demi kepentingan persuasi politik, konsensus moral pun didominasi oleh negara. Tetapi jelas bahwa pengaruh agama tidaklah remeh sebab dapat mempengaruhi politik dan kekuatan yang menentukan dalam pengaruh kebudayaan lewat simbol-simbol yang kerap dipergunakan dalam wacana politik. Sebenarnya negara modern dengan spesifik-legislatif dan membludaknya berbagai aturan dapat mengurangi penentuan nasib masyarakat dan memenuhi kebutuhan dasarnya. Tetapi masyarakat sipil tetap mempercayai negara sebagai pengayom kehidupan mereka. ${ }^{8}$

Para imigran Muslim terkonsentrasi pada daerah-daerah tertentu negara Eropa Barat, mereka mulai merasa penting terhadap Masjid dan organisasi, sebagaimana ketika mereka berada di negara-negara asalnya. Sejak awal Islam dibawa oleh penaklukan arab ke Afrika Utara, Spanyol, Sisilia, dan beberapa wilayah pantai laut Tengah di Eropa. Beberapa masyarakat Turki dia Asia Tengh, dan migrasi, penaklukan, dan pendirian imperium mereka. Dari abad ke10-14, masyarakat Turki membawa Islam ke arah barat sampai ke Anatolia,

\footnotetext{
${ }^{8}$ Ibid, hlm. 331 .
} 
Balkan, Eropa Tengah, ke arah timur bahkan sampai ke Asia Tengah dan China.

Kemajuan Eropa (Barat) memang bersumber dari khazanah ilmu pengetahuan dan metode berpikir Islam yang rasional. Di antara saluran masuknya peradaban Islam ke Eropa itu adalah Perang Salib, Sicilia, dan yang terpenting adalah Spanyol Islam. Ketika Islam mengalami kejayaan di Spanyol, banyak orang Eropa yang datang belajar ke sana, kemudian menerjemahkan karya-karya ilmiah umat Islam. Andalusia merupakan jembatan utama peradaban Islam dan gerbang untuk proses transmisi dan transfer peradaban Islam ke Eropa. Berbagai bidang kemajuan seperti bidang sains, pemikiran, sosial, ekonomi, hukum, falsafat, seni, dan sebagainya. Selama delapan abad (711-1492) mimbar pencerahan peradaban dibangun di sana. ${ }^{10}$ Setelah mereka pulang ke negeri masing-masing, mereka membangun universitas dengan meniru pola Islam dan mengajarkan ilmu-ilmu yang dipelajari di universitas-unversitas Islam itu. Dalam perkembangan selanjutnya, keadaan ini melahirkan renaissance, reformasi, dan rasionalisme di Eropa. ${ }^{11}$ Demikianlah seterusnya bahwa peradaban Islam di Spanyol banyak menghasilkan pencapaian sosial budaya serta kemajuan di bidang ilmu pengetahuan yang sampai hari ini menjadi refrensi peradaban. ${ }^{12}$

\section{Pola-Pola Pendidikan Agama Umat Islam}

Sebagaimana lazimnya sebuah komunitas, maka terbentuknya struktur organisasi menjadi sebuah keniscayaan dengan demikian mulailah struktur sosial terbangun. Hal selanjutnya yang secara otomatis akan terbentuk adalah lembagalembaga sebagai wadah penyiaran Islam. Mesjid merupakan sarana ibadah yang paling pertama kali dibangun dalam rangka menyebarkan Islam. Dalam tradisi Islam klasik, mesjid merupakan lembaga pendidikan Islam paling awal. Pada awal kemunculan Islam memang mesjid dijadikan sebagai pusat pendidikan disamping sebagai tempat beribadah.

${ }^{9}$ Ghufron A. Mas'adi, Sejarah Sosial Umat Islam (Jakarta: PT Raja Grafindo Persada. 2012), hlm. 374.

${ }^{10}$ Yoyo Hambali, "Sejarah Sosial dan Intelektual Masyarakat Muslim Andalusia dan Kontribusinya Bagi Peradaban Dunia”, dalam Jurnal Ilmu Ushuluddin, Vol. III, no. 1, Januari-Juni (2016), hlm. 64.

${ }^{11}$ Badri Yatim, Sejarah Peradaban Islam (Jakarta: PT. Raja Grafindo Persada, 2010), hlm. 169.

${ }^{12}$ Dedi Sahputra Napitupulu, "Romantika Sejarah Kejayaan Islam di Spanyol", dalam Jurnal Mukaddimah, Vol. III, no. 1, Januari-Juni (2019), hlm. 7. 
44 | Belajea: Jurnal Pendidikan Islam, Vol. 5, No. 01, 2020

Demikian pula masuknya ajaran Islam ke suatu daerah, tidak bisa dilepaskan dari pengaruh pendidikan. Saat itu, mengajarkan agama Islam masih memakai metode dakwah, yaitu seperti ceramah dan dialog interaktif. Agama Islam sebagai agama perdamaian sangat mudah diterima oleh masyarakat Indonesia hal tersebut terbukti dengan mudah agama Islam diterima di kalangan masyarakat Indonesia. Dalam proses pembentukan dan pengembangan masyarakat Islam yang juga melalui kontak, misalnya kontak jual beli, perkawinan dan keadaan tersebut berlangsung secara individual dan kolektif. ${ }^{13}$ Hal ini juga berlaku untuk kasus di Eropa. Akan tetapi di Eropa banyak lagi variabel yang menyebabkan Islam menyebar luas seperti dunia penelitian, hiburan dan olah raga.

Para Ilmuan Barat banyak yang mengkaji Islam kemudian melakukan penelitian, yang penelitiannya itu membuktikan kebenaran Alquran sehingga pada akhirnya para ilmuan Eropa berbondong-bondong masuk Islam. Faktor lain adalah melalui dunia entertaint (hiburan) seperti olah raga. Banyak olahragawan katakan lah yang masyhur belakangan ini adalah pesepak bola yang berasal dari negara-negara Islam mereka mengadu nasib ke Eropa kemudian karena skill dan kemampuan mereka sehingga mereka menjadi terkenal. Ketika para pendatang Muslim menjadi terkenal dalam dunia sepak bola maka akan menimbulkan kesan yang baik kepada orang-orang Eropa.

Menurut data yang diperoleh bahwa 67,4 persen orang tua memasukkan anaknya ke sekolah negeri, dan sekitar 26 persen ke sekolah swasta yang dibiayai oleh pemerintah, dan 6,6 persen sekolah swasta murni. Walaupun pengajaran Islam dan bahasa Arab telah resmi diterapkan, tetapi masih sedikit sekali jumlah lembaga pendidikan Islam khusus. ${ }^{14}$ Jadi hampir di seluruh negara Eropa pendidikan Islam telah melebur ke dalam kurikulum pendidikan Nasional Eropa. Dalam konteks pendidikan agama Islam, masyarakat Muslim Eropa selalu termotivasi dengan semangat agama dalam dalam menanamkan ajaranajaran Islam melalui pendidikan. Hal ini tidaklah bertentangan demngan konsep kenegaraan Eropa sehingga pendidikan Islam terus berjalan.

Sistem pendidikan terpadu yang diterapkan oleh pemerintah Eropa memberikan pertimbangan tersendiri kepada Muslim di sana, terutama untuk memasukkan anak mereka ke lembaga pendidikan yang dikelola oleh

\footnotetext{
${ }^{13}$ Hasbullah, Sejarah Pendidikan Islam di Indonesia: Lintasan Sejarah dan Perkembangan (Jakarta: Raja Grafindo Persada, 1999), hlm. 20.

${ }^{14}$ Musyrifah Sunanto, Sejarah Islam Klasik: Perkembangan Ilmu Pengetahuan Islam (Jakarta: Kencana, 2007), hlm. 38.
} 
pemerintah. Agar ajaran Islam daapat diterima di Eropa maka sedikit demi sedikit konsep pengamalan ajaran Islam dimmasukkan pada lembaga pendidikan di Eropa. Diantaranya adalah pada tahun 1974 dibentuknya Asosiasi Orang Tua Muslim di Brandford Inggris dalam mendukung kebijakan sistem pendidikan tentang single sex atau pemisahan antara murid laki-laki dan perempuan. Orang tua murid mendapatkan kebebasan dalam memilih sekolah terbaik untuk anakanak mereka. Orang tua masing-masing, memiliki preferensi dalam memilih sekolah. Kelompok-kelompok minoritas di seentaro Inggris menikmati perlakuan dan perlindungan yang sama. Sehingga persoalan mayoritas maupun minoritas bukanah sebuah diskursus yang mengemuka. ${ }^{15}$ Terdapat tiga pola pendidikan yang digunakan masyarakat muslim Inggris untuk pendidikan bagi keluarganya yaitu sekolah negeri, sekolah swasta, dan sekolah komunitas. ${ }^{16} \mathrm{Di}$ sisi lain tentang kurikulum pendidikan Eropa yang tidak sejalan dengan Islam maka diformulasikan satu konsep agar peserta didik Islam dapat mengikutinya tetapi dalam konteks yang sudah diformulasikan dalam Islam.

Pendidikan Islam dipengaruhi oleh realitas atau kenyataan perubahan sosial, lingkungan sosio kultural, dalam arti penentuan sistem pendidikan, institusi dan pilihan-pilihan prioritas juga eksistensi dan aktualisasi dirinya. ${ }^{17}$ Sementara itu, di dunia Barat pola pendidikan agama yang ditempuh, khususnya di daerah minoritas adalah dengan memaksimalkan fungsi masjid sebagai pusat kegiatan umat. Sehingga masjid tidak hanya dijadikan sebagai tempat ibadah semata, akan tetapi juga sebagai pusat perekonomian, politik, dan pendidikan. Secara teknis masjid-masjid yang ada dijadikan semacam kelas-kelas kecil bagi lembaga pendidikan dalam bentuk majelis ta'lim. Di sisi yang lain, kebutuhan akan ulama atau ustadz yang mampu membimbing mereka sangat penting. Akan tetapi oleh karena kelangkaannya, maka penduduk Muslim di daerah minoritas mengimpor ustasdz dari daerah lain.

Pada jenjang pendidikan yang lebih tinggi lagi, pola pendidikan penduduk Muslim minoritas memilih untuk meneruskan pendidikan agama pada jenjang Perguruan Tinggi ke negara-negara yang berpenduduk mayoritas Muslim. Karena di negara asal mereka tidak ditemukan lembaga pendidikan

${ }^{15}$ J. Lindley, "The Over-education of UK Immigrants and Minority Ethnic Groups: Evidence From The Labour Force Survey", dalam Jurnal Economics or Education Review, Vol. XXVIII, no. 1,Februari (2009), hlm. 80.

${ }^{16}$ Ismail Suardi Wekke dan Ambo Tang, "Kultur Pendidikan Islam di Minoritas Muslim Inggris”, dalam Jurnal Thaqafiyat, Vol. XVII, no 1, Januari-Juni (2016), hlm.70.

${ }^{17}$ Azyumardi Azra, Pendidikan Islam: Transisi dan Modernisasi Menuju Milinium Baru (Jakarta: Logos Wacana Ilmu, 2000), hlm. 64. 
46 | Belajea: Jurnal Pendidikan Islam, Vol. 5, No. 01, 2020

Islam yang mampu menyahuti kebutuhan mereka. Anehnya, belakangan ini malah negara negara yang minoritas Muslim membuka kampus dengan kajiankajian keislaman (Islamic Studies), seperti Canada dan California di USA. Ternyata penggemar kajian-kajian keislaman di negara yang minoritas muslim sangat banyak, dan kampus-kampus yang menyediakan kajian keislaman tersebut sangat berkembang dan maju.

\section{Prospek dan Tantangan}

Peristiwa 11 September yang menggoncangkan dunia, merupakan satu sebab penting yang menjadikan perhatian dunia bertanya-tanya tentang Islam. Namun upaya pengkajian Islam yang intensif, terutama oleh para pemikir studistudi agama dunia, di Barat lah penyebab utama perkembangan umat Islam dan sekaligus kajian studi Islam di dunia. ${ }^{18}$ Dalam Situasi yang sulit, biasanya akan memaksa seseorang untuk berpikir keras agar segera keluar dari kesulitan tersebut. Semangat perjuangan akan muncul dan biasanya, orang-orang yang berada dalam situasi terjepit akan lebih kreatif mencari solusi. Kondisi ini sama sekali tidak dianggap sebagai penghambat, akan tetapi merupakan peluang besar yang harus dimaksimalkan. Sebagaimana yang telah diungkapkan pada bagian terdahulu bahwa, banyak kampus-kampus yang mengkaji dan mendalami Islam padahal secara geografis mereka berada di wilayah minoritas. Hasilnya cukup memuaskan, studi keislaman di sana berkembang pesat dan ramai penggemar.

Orang yang berada di daerah minoritas akan lebih mengamalkan Islam secara kaffah (sempurna). Lihat saja orang-orang yang baru masuk Islam (muallaf), pada umumnya, semangat mereka dalam menerapkan ajaran Islam, diatas rata-rata dariorang yang sudah Islam karena keturunan. Demikian pula halnya dengan penduduk Muslim minoritas, karena mereka berada dalam realitas komunitas yang minim, maka ada semacam motivasi dan semangat untuk menampilkan citra Islam yang lebih baik.

Peluang-peluang di atas memang lebih bersifat normatif, pada saat yang sama beragam tantangan yang dihadapi oleh penduduk Muslim di daerah minoritas juga tidak dapat dielakkan. Berikut ini merupakan uraian tentang ragam tantangan yang di hadapi:

1. Orientasi yang kurang jelas. Pendidikan Islam saat ini, dari berbagai terlihat seperti tak tentu arah, hal ini disebabkan karena orientasi yang

${ }^{18}$ M. Rusydi, “Dinamika Studi Islam di Barat”, dalam Jurnal Studia Insaniyah, Vol. IV, no. 1, Januari-Juni (2016), hlm. 57. 
kurang jelas. Harusnya sistem pendidikan Islam senantiasi kepada kepada menjawab kebutuhan dan tantangan yang muncul dalam masyarakat kita sebagai konsekuensi logis dari perubahan. ${ }^{19}$ Jika hal ini tidak dilakukan maka pendidikan Islam di Indonesia akan mengalami ketinggalan dalam persaingan global. Lembaga pendidikan Islam sekarang lebih pada orientasi yang bersifat transfer of knowledge and skill saja. Dalam mengembangkan proses intelektualisasi dan kurang memperhatikan dalam pembinaan spiritual dan disiplin moral yang islami.

2. Sumber daya manusia yang dimiliki oleh lulusan Muslim belum mencukupi dan masih rendah mutunya, maka diharapkan mutu lulusan di sekolah atau Perguruan Tinggi Islam dapat menghasilkan sumber daya manusia yang dapat berdaya saing di era globaliasasi ini sehingga mempunyai nilai jual yang siap kerja. Semua permasalahan yang memperlemah kondisi umat harus diselesaikan melalui upaya strategis dalam memperkuat sumber daya umat Islam dengan cara memperoleh pendidikan keterampilan mulai dari bahasa asing, dan penguasaan teknologi informasi serta pemberian beasiswa untuk belajar ke dalam dan luar negeri sehingga menghasilkan sumber daya manusia yang berkualitas dan berdaya saing. Hendaknya setiap individu harus memiliki landasan dan kemampuan yang meliputi perilaku, kerja keras disiplin, tanggung jawab yang dapat dipercaya. ${ }^{20}$

3. Minimya anggaran yang disediakan oleh negara. Ini juga mmenjadi permasalahan yang cukup serius. Terutama di negara-negara dengan penduduk yang minoritas, bagaimana mungkin pemeritah mau memberikan anggaran yang lebih untuk mengembangkan pendidikan Islam, di daerah yang pemimpinnya bukan Islam?. Secara politik memang mustahil. Oleh karena itu, para pengelola lembaga pendidikan hendaknya kreatif dalam hal pengumpulan dan pengelolaan dana dengan menjalin kerja sama dengan negara-negara Islam. Kita sangat memaklumi bahwa anggaran pendidikan di hegara dengan penduduk yang minoritas sangat terbatas. Meminjam istilah Agus Irianto bahwa

\footnotetext{
${ }^{19}$ Azra, Pendidikan Islam, hlm. 57.

${ }^{20}$ Komaruddin Hidayat, Agama Masa Depan: Perspektif Filsafat Perennial (Jakarta: Paramadina, 1995), hlm. 114.
} 
48 | Belajea: Jurnal Pendidikan Islam, Vol. 5, No. 01, 2020

anggaran pendidikan belum memadai dan oleh karenanya memerlukan bantuan dari berbagai pihak. ${ }^{21}$

Ketiga tantangan di atas adalah sebagian kecil dari banyak tantangan yang dihadapi oleh penduduk Muslim di daerah minoritas. Beragam tantangan lainnya jika ingin ditambah masih banyak lagi seperti kurikulum pendidikan agama yang cenderung stagnan, kecenderungan terhadap Barat (padahal kajian keislaman sesungguhnya berasal dari Timur), dan pengaruh arus globalisasi yang begitu kuat.

Tantangan ini merupakan tantangan kita bersama, tidak boleh hanya dibebankan kepada saudara-saudara kita yang berada di adaerah minoritas saja. Oleh karenanya, jalan keluar dari tantangan tersebut adalah tidak ada cara lain melainkan umat Islam di seluruh dunia harus mengambil bagian dalam membantu saudaranya yang ada di daerah minoritas. Banyak hal yang bisa dilakukan seperti dengan memaksimalkan fundraising dalam tradisi Islam yaitu optimalisasi dana zakat, infak, wakaf, dan sedekah untuk membantu pembiayaan lembaga-lembaga pendidikan di negara-negara Minoritas Muslim.

\section{Kesimpulan}

Berdasarkan uraian terdahulu, maka tulisan ini dapat disimpulkan sebagai berikut:

1. Data statistik menunjukkan bahwa ada sekitar 1,8 miliyar penduduk Muslim yang tersebar di seluruh penjuru dunia. Pola pertumbuhan Muslim abad 20-21 adalah melalui tingkat kelahiran penduduk Muslim yang lebih tinggi dari angka kematian. Selanjutnya yang menjadi modus perpindahan umat Muslim kenegara-negara minoritas adalah karena konflik yang berkepanjangan di negara asal mereka. Selain itu, penyebab yang paling utama dalam hal penyebaran muslim adalah faktor ekonomi yang lebih menjanjikan di negara-negara Barat (minoritas Muslim).

2. Adapun pola-pola pendidikan Muslim minoritas adalah dengan memaksimalkan fungsi masjid sebagai lembaga pendidikan Islam, mendirikan majelis taklim dan madrasah. Pada jenjang pendidikan yang lebih tinggi lagi, pola pendidikan penduduk Muslim minoritas memilih untuk meneruskan pendidikan agama pada jenjang Perguruan Tinggi ke negara-negara yang berpenduduk mayoritas Muslim. Anehnya,

\footnotetext{
${ }^{21}$ Agus Irianto, Pendidikan Sebagai Investasi dalam Pembangunan Suatu Bangsa
} (Jakarta: Kencana, 2013), hlm. 11. 
Dedi Sahputra, dkk: Pendidikan Islam Muslim Monorotas

belakangan ini malah negara negara yang minoritas Muslim membuka kampus dengan kajian-kajian keislaman (Islamic Studies).

3. Adapun yang menjadi peluang umat Muslim di daerah minoritas adalah dorongan dan motivasi yang kuat untuk segera keluar dari tekanan. Sedangkan yang menjadi penghambat adalah orientasi pendidikan yang kurang jelas, sumber daya manusia (SDM) yang belum memadai, dan minimnya anggaran.

\section{Bibliography}

Asari, Hasan. Menyingkap Zaman Keemasan Islam. Bandung: Mizan, 2007.

Azra, Azyumardi. Pendidikan Islam: Transisi dan Modernisasi Menuju Milinium Baru. Jakarta: Logos Wacana Ilmu, 2000.

Hitti, Philip K. History of Arabs, Terj. Cecep Lukman Yasin dan Dedi Slamet Riyadi. Jakarta: Serambi Ilmu Semesta, 2010.

Hambali, Yoyo. "Sejarah Sosial dan Intelektual Masyarakat Muslim Andalusia dan Kontribusinya Bagi Peradaban Dunia", dalam Jurnal Ilmu Ushuluddin, Vol. III, no. 1, Januari-Juni. 2016.

Hasbullah. Sejarah Pendidikan Islam di Indonesia: Lintasan Sejarab dan Perkembangan. Jakarta: Raja Grafindo Persada, 1999.

Hayat, Bahrul. "Kontribusi Islam Terhadap Masa Depan Peradaban Islam di Asia Tenggara", dalam Jurnal Miqot, Vol. XXXIV, No. 1, Januari-Juni 2012.

Hidayat, Komaruddin. Agama Masa Depan: Perspektif Filsafat Perennial. Jakarta: Paramadina, 1995.

Irianto, Agus. Pendidikan Sebagai Investasi dalam Pembangunan Suatu Bangsa. Jakarta: Kencana, 2013. 
50 | Belajea: Jurnal Pendidikan Islam, Vol. 5, No. 01, 2020

Lindley, J. "The Over-education of UK Immigrants and Minority Ethnic Groups: Evidence From The Labour Force Survey", dalam Jurnal Economics or Education Review, Vol. XXVIII, no. 1,Februari. 2009.

Mas'adi, Ghufron A. Sejarah Sosial Umat Islam. Jakarta: PT Raja Grafindo Persada. 2012.

Napitupulu, Dedi Sahputra. "Romantika Sejarah Kejayaan Islam di Spanyop", dalam Jurnal Mukaddimah, Vol. III, no. 1, Januari-Juni. 2019.

Poradisastra, S.I. Sumbangan Islam Kepada Ilmu dan Peradaban Dunia. Jakarta: P3M, 1986.

Pew Research Center's Forum on Religion \& Public Life, World Muslim Population by County, dirilis pada 17 November, 2017.

O’Callagan, Joseph F. A History of Medieval Spain. New York: Cornell University Press, 1983.

Rusydi, M. "Dinamika Studi Islam di Barat", dalam Jurnal Studia Insaniyah, Vol. IV, no. 1, Januari-Juni. 2016.

Sunanto, Musyrifah. Sejarah Islam Klasik: Perkembangan Ilmu Pengetahuan Islam. Jakarta: Kencana, 2007.

Thohir, Ajid. Perkembangan Peradaban Dunia Islam: Melacak. Akar-Akar Sejarah, Sosial, Politik, dan Budaya Umat Islam. Jakarta: Rajawali Press, 2009.

Wekke Ismail Suardi dan Ambo Tang, "Kultur Pendidikan Islam di Minoritas Muslim Inggris”, dalam Jurnal Thaqafiyat, Vol. XVII, no 1, Januari-Juni. 2016.

Yatim, Badri. Sejarah Peradaban Islam. Jakarta: PT. Raja Grafindo Persada, 2010 . 